\title{
Aural Space, Sonorous Presence, and the Performance of Christian Community in the Chester Shepherds Play
}

\begin{abstract}
Sensitivity to the Chester Shepherds'soundedness in performance reveals that its climactic action - an angel singing a sophisticated Gloria, its audience of shepherds responding with playful macaronic Latin — stands not as an isolated outburst but rather as the concentrated centre of a thoroughgoing network of meaning ful sound that stretches from the play's first to its last line. By reading the Chester Shepherds play with ears attuned to its sounded dimension, we gain insight into how the play fostered opportunities for interanimating presence, identity, and community by manipulating the aural space of late-medieval theatrical enactment to draw an audience into sonorous presence. The play patterns sounds, verbal and otherwise, into a meaning-bearing experience of sound in its own right in order to develop a dynamic acoustic space in which present sounding and hearing can become the fulcrum of redemptive meaning and salvific Christian membership.
\end{abstract}

Halfway through the Chester Shepherds play, soon after its youngest herdsman bests his elders in a postprandial wrestling contest, the continuity of the play's dramatic world and of its theatrical enactment undergoes a sudden, pivotal interruption. So far, the play has proceeded in the mode of a pastoral farce, but now a shining star appears to the shepherds, dazing them with its brilliance, and an angel announces the nativity, singing out the words of Luke 2:14 in a sophisticated flourish of song. This interruption represents a turning point in salvation history: moments after Trowle trounces his boastful employers, a type of the lowly putting down the mighty from their seat, ${ }^{1}$ Jesus overturns nature and vanquishes the devil through his birth, a victory revealed not to kings, priests, or patriarchs but to shepherds, humble peasants like much of the play's late-medieval audience. Dramaturgically the divine apparition provides ample opportunity for spectacular display which we might consequently expect to see reflected in the shepherds' dialogue. In

Andrew Albin (aalbin@fordham.edu) is assistant professor in the department of English at Fordham University at Lincoln Center. 
the Chester Shepherds play as in all the cycle shepherds plays, however, this climactic episode is most notable for its overwhelming emphasis not on sight but on sound, both the celestial sounds that reach the shepherds' ears and the more mundane sounds that the awe-struck herdsmen generate in reply. They have only begun to note the star's brilliance when they are cut off by the angel's song whose poorly understood meaning they discuss at length and whose elaborate melody and Latin lyric they go on to imitate to the best of their ability, fitting the angel's good news to their own tongues, repeating its words in the vernacular accents of their own voices.

Critics have read this deservedly celebrated passage, an almost eighty-line colloquy concerning the angel's sounds, in two ways: as carnivalesque parodying of learned Latinate discourse or as musicological evidence for reconstructing late-medieval performance practice. ${ }^{2}$ Approached from a different angle, however, this passage and the sonorous negotiations surrounding it reveal significantly richer possibilities. The angel's song introduces Christ's harmonization of divinity and humanity into the quiescent midnight world of the shepherds' vigil, inaugurating Christian community through choral song and transposing the shepherds' fallen world into a new soteriological context of divine grace as expressed through music. The inhabitants of such a newly redeemed world must learn how to hear and how to sound anew within the novel framework of salvation. Indeed, the shepherds' strikingly energetic fascination with the angel's sound and their urgent desire to make meaningful sense of its song points to the special potency of sound in advancing the notion of salvation the play elaborates. Likewise we can conceive the sounds of the Chester Shepherds in performance as bearing a cognate potency able to touch late-medieval English audiences outside the play's dramatic world. In fact when we read the play sensitive to its soundedness in performance, the angel's pivotal song and the shepherds' playful outpouring of macaronic Latin emerge not as isolated outbursts of sonorous play but rather as the concentrated centre of a thoroughgoing network of meaningful sound that stretches from the play's first to its last line.

By reading the Chester Shepherds play with ears attuned to its sounded dimension, we can thus gain insight into how the play's performance in the public spaces of late-medieval Chester fostered opportunities for interanimating presence, identity, and community within living systems for sonorous meaning. I term these systems auralities: the cultural frameworks through which sound events become meaningful as heard experience. Taking resourceful advantage of flexible dramaturgical conventions, the Chester 
Shepherds play designs, articulates, and manipulates a sequence of 'scenes of hearing' in the physical space of performance, what I term aural fields, in order to sponsor a transformation of aurality that bridges the theatrical boundary to envelop the listening audience. Its careful and deliberate patterning of sounds, verbal and otherwise, into the meaning-bearing experience of sound as sound allows the play to develop a dynamic acoustic space in which players and audience may become mutually present to one another through sound. In such a space, present sounding and hearing can become the fulcrum of redemptive meaning and salvific Christian membership.

\section{Relational Presence and the Echolocative 'Howe'}

One characteristic feature of late-medieval vernacular theatre is the malleability of the playing space in which the enactment occurs. Research into historical performance practice has revealed that the formal boundary of late-medieval playing spaces was remarkably fluid and flexible: performances on pageant wagons regularly spilled out into the surrounding streets while place-and-scaffold performances may very well have seated audiences in between scaffolds or even in the central playing space itself. ${ }^{3}$ Medieval dramatists took creative advantage of this fluid spatiality using a technique Hans-Jürgen Diller calls 'straddling', 'the oldest ... most complex and most interesting' way medieval theatre bridged the actors' dramatic world inside the theatrical boundary and the audience's everyday world outside it. ${ }^{4}$ To elaborate Diller's definition, 'straddling' is a mode of theatrical utterance that blurs the line between these worlds, allowing personae from within the drama to address an audience directly such that both personae and audience members are present to one another in either world or in both at once; previous to the utterance they inhabited formally discrete spaces across which they did not relate to one another as mutually present, according to the conventions governing theatrical performance.

Straddling utterances thus adjust the rules of the theatrical game, temporarily modifying the formal framing of dramatic space to permit the mutual presence of hearing audience and speaking persona in a provisional auditory space that encompasses both. Consequently a transformation in auralities occurs: before straddling, two modes of meaningful sound-making exist, one inside the dramatic world governing the sounding and hearing practices of that world's socially situated personae, the other outside the dramatic world governing the sounding and hearing practices of the drama's audience 
members who are situated within their respective social (and theatrical) surroundings. The coexistence of differing sonorous regimes reinforces the formal distinction between dramatic and real worlds; after the straddling utterance bridges this boundary and establishes a shared social setting, though, personae and audience coexist under the same framework for making meanings out of sounds. The straddling utterance thus can be said to launch a 'scene of audition', an aural field, that crosses the theatrical boundary, folding an audience into a shared aurality in which personae and audience are for a time subject to the same rules and relationships to sounds.

Such utterances are especially important and frequent at the beginnings of plays, where they offer players a dramatically coherent means of indicating that the play has begun in the absence of conventionally inaugurating visual signals like lifting curtains or lighting changes. As Herod's and Pilate's opening pronouncements in the York trial plays exemplify, these addresses often employ the modes of speech and action upon which social hierarchy is built to count the audience among the inhabitants of the dramatic world and call them to silence, here as subjects before their socially superior interlocutors: 'Pes, ye brothellis and browlys in pis broydenesse inbrased, / And freykis pat are frendely your freykenesse to frayne, / Youre tounges fro tretyng of triffillis be trased' (31.1-3); 'Pees, bewscheres, I bidde you, pat beldis here aboute me, / And loke pat ze stirre with no striffe, but stande stone still' (32.1-2). ${ }^{5}$ Such utterances effectively fold the audience into the formal space of theatrical enactment, incorporating them into the diegetic world, while at the same time establishing the hushed auditory conditions necessary for the play's performance, a resourceful solution to the practical and dramatic problem of how to start the play.

While this use of straddling utterance to start the dramatic action appears in other plays in the Chester cycle and in shepherds plays from other mystery cycles, the Chester Shepherds play elects a somewhat different method for establishing an initial aural field in which meaningful theatrical audition can occur. This play begins by presenting a lone man on an empty stage bemoaning his harsh natural environment, praising his own good husbandry, and reviewing folk remedies for livestock ailments in a long speech that at times resembles a self-directed soliloquy, at times an aside addressed to a listening audience. Small verbal gestures like the interjectional 'Loe' in line 17 or the emphatic 'I tell yt you' in line 25 acknowledge the presence of others to whom the as-yet-unnamed figure directs his address, but this is not the same kind of straddling work as occurs at the outset of the York trial 
plays. Audience members are not folded into the dramatic world inside the theatrical boundary; their space is not annexed to that of the stage, neither does the persona's utterance situate the audience within a coherent social framework native to the dramatic world. Instead his words serve to showcase himself and his environs just as they are, as formal, theatrical inventions, to an audience that is wise to the game. He speaks from across the theatrical divide; his shepherding fields end at the playing space's edge while his audience remains firmly located in Chester, England. The verbal traffic between these spaces carries more than a note of theatrical self-consciousness.

As his speech comes to a close, the shepherd we soon learn to call Hankyn crystallizes the exclusionary construction of his dramatic space at the Chester Shepherds play's outset, going out of his way to define the boundaries and membership of a diegetic aural field smaller than the full spread of acoustic space and delimited by the edges of the playing space, to which the audience does not belong. Hankyn concludes his speech by emphasizing his aloneness inside the dramatic world: 'noe fellowshippe here have I / save myselfe alone, in good faye' (7.41-2). ${ }^{6} \mathrm{He}$ is by 'myselfe alone', his words eliminating from presence the audience that Hankyn has half-addressed since the beginning of the play. This exclusion occurs without provoking disorientation precisely because the play never incorporated the audience into the dramatic world and its distinctive aurality in the first place. As if to reiterate the audience's exclusion from dramatic space, Hankyn punctuates this declaration of sole presence with a gesture that does not appear to make much dramatic sense: 'But first will I drinke, if I maye' (7.44), he says, pulling out a wine-skin. Certainly Hankyn's sudden thirst gives the player representing him a chance to caricature the stock drunkard to comic effect. The move is also entirely intelligible with respect to the aural field as Hankyn has constructed it: without any present fellow to share his drink with, Hankyn's swallows interrupt his speech and reiterate his aloneness in sounding space at the same time that his audience's laughter marks the end of his soliloquy, helping to advance the performance and usher in the transformations of the sonorous dramatic world that shortly follow.

If we meditate further on Hankyn's words, they betray a much more sophisticated aurality than his insistence upon his solitude might at first suggest. Though surrounded by people of whom he is in some sense aware, Hankyn can declare that he is by 'myselfe alone' inside the diegetic aural field because its definition excludes the audience from 'fellowshippe', a term which in the Chester Shepherds play comes to signify mutual presence in 
and through sound. Revealingly, once he realizes he lacks company, Hankyn feels compelled to cry out into the wilderness for a companion: he is alone and 'therefore after one faste wyll I crye' (7.43), he declares. Bolstered by the logically consequential force of his 'therefore', the immediacy of Hankyn's compulsion to cry out indicates a crucial aspect of his conception of self, namely that it is fundamentally relational in design. For him, being 'myselfe alone' is only comprehensible in the context of 'fellowshippe'; in order to be present to himself, in order for his own speech to be properly termed a voice, Hankyn cannot be alone but requires a present other to hear him. That is to say, in the Chester Shepherds play, becoming present to oneself, constituting oneself as a speaking, envoiced subject who is capable of observing his own aloneness, demands the presence of an other who can receive and reflect back the effects of the summoning voice, an exchange that here plays out in the realm of the relational, social quotidian, the banal everyday of the shepherding pasture.

In so quickly resolving to cry out for an other, Hankyn thus assigns to sound a key relational function through which he may establish his own presence to others, a process he goes on to enact in his ensuing lines. Resonant with loud 'ow' vowels, he cries out to his fellow shepherd Harvye as if invoking him:

Howe, Harvye, howe!

Drive thy sheepe to the lowe.

Thow may not here excepte I blowe

As ever have I heale.

A stage direction in BL Ms Harley 2124, the latest and most detailed of the Chester cycle manuscripts, reveals that Hankyn's cry of 'Howe' propagates many times over once it is emitted, first with a blast from his hunting horn and then with a triple echo: 'Tunc flat cum Cornu et reddit Aho.io.o.' (7.48 sd). This stage direction, a ricocheting elaboration of 'ow' in various timbres, is thought-provoking for performance practice as much as for its participation in the play's evolving aurality. To begin with performance practice: what might these effects actually have sounded like? Richard Rastall reasonably argues that the actor playing Hankyn would have blown an ox-horn for the initial blast ${ }^{7}$ but the echo is a trickier question, in large part because of the potential ambiguity surrounding who or what 'reddit'. Most simply the stage direction could indicate that Hankyn is again to cry out after blowing his horn, but the grammatical actor who performs the verb reddit could also be 
the other shepherd to whom Hankyn cries or even the 'Cornu' itself, capitalized like a proper name in the manuscript, as its sound echoes back against the surrounding diegetic environs.

Though this last may seem the least likely possibility, entertaining the idea can in fact help clarify the more likely options with respect to the play's early aurality. Again on the level of practice, the bustling, noisy streets of Chester during a summertime festival would not permit a natural echo of any sort, least of all from Hankyn's horn blast. The stage direction reflects this acoustic difficulty by scripting the echo into the play's performance, writing it out as the spoken mimic of an echo perhaps voiced from offstage with a touch of comedy by the actor awaiting his entrance as Harvye, the summoned shepherd. That is to say, as an echo, 'Aho.io.o.' is imagined to exist not just as a sound event but as a spoken event, is recorded in the play-script as a verbal utterance within language, and was likely perceived and construed the same way by its audience. This observation need not lead to the conclusion that 'Aho.io.o.' must represent a verbal call and therefore cannot represent the horn blast's echo; rather we can take the stage direction to indicate a key aspect of the play's early aurality: as the horn blast echoes off the diegetic world's imagined landscape, the sound it returns is no mere acoustic reflection but instead a voice speaking in language.

In this respect we can construe the sequence of sound events that comprises Hankyn's cry as a kind of presence-effecting echolocation. The horn blast carries Hankyn's 'Howe' to strike some responsive thing 'out there' on the margins of the aural field, and as his 'Howe' rebounds, its echo returns a verbal utterance, 'Aho.io.o.' Crucially this echo possesses a distinct speaking voice, one that repeats Hankyn's resonant 'ow' vowels to him as it punctuates the entrance of a new persona into the dramatic world and grants Hankyn the 'fellowshippe' he needs to come into presence to himself. Indeed, if the offstage actor playing Harvye is the one to speak 'Aho.io.o.', the complex of sounds participating in the exchange - 'Howe', the horn blast, the horn blast's echo, 'Aho.io.o.', and the other's voice - assemble into the unfolding of this echolocative process such that, as Harvye steps on stage, he embodies the presence-granting reverberation that Hankyn seeks and that the dramatic world's aurality provides. 


\section{Historical Phonology and Hankyn's Summoning Vowel}

Understanding 'Aho.io.o.' in this fashion also helps us address one of the more difficult problems attending inquiry into the historical experience of verbal sound, namely the phonological values of the play's words as they were spoken in the past moment of performance. In the intractable absence of sound recordings or even orthoepic literature for the period, medieval manuscripts make notoriously fickle resources for studying historical phonology. As Angus McIntosh points out regarding written texts in general, 'graphic units are not designed to carry some bits of phonic information at all'. The functions of writing are not equivalent to those of speech; not only may '[t]he letter-units out of which [a] text is mainly made up ... convey different phonic messages to different readers' and be differently put into voice by different speakers, but, when dealing with historical texts written in bygone languages, we enter into an especially 'hazardous undertaking' when we try to make empirical claims about the sounds such texts generated in the day and age of their original composition. ${ }^{8}$ Historical phonology is, we do well to remember, always a form of historical storytelling.

That said, dialectological work on the multiple Englishes of the late middle ages and especially on the northwest Midland dialect region where Chester was situated bears importantly on the phonological relationship between Hankyn's 'Howe' and 'Aho.io.o.' Received wisdom about the pronunciation of middle English would suggest that associating the vowels of these two utterances is tenuous at best. Middle English $<\mathrm{ow}>$ is generally accepted to represent /u:/, while Latin <o> represents /o:/, two distinct phonemes (even if separated by just one vertical degree). Roger Lass reminds us, though, that 'histories of English tend to be tilted southwards' towards London," and a somewhat different linguistic profile emerges when we reorient our inquiry northwest. While Chester's dialect has not seen dedicated investigation, that of its immediate regional neighbours has: John McLaughlin has authored a meticulous study of the graphonemics of BL Ms Cotton Nero A.x, the Pearl manuscript, whose authorial and scribal dialects have been localized to northwest Derbyshire and south Lincolnshire, hugging Chester to its immediate north, and dated to the late-fourteenth/early-fifteenth century, within fifty years of the earliest documentary reference to the Chester cycle in $1422 .{ }^{10}$ That is to say, the Pearl manuscript's poems and the Chester Shepherds play were composed in approximately the same dialect region at approximately 
the same time, and so phonological investigation of the one should within reason pertain to the other.

When we compare the manuscripts side by side, though, orthography, graphemics, lexis, indeed, most features would seem to belie any such applicability. We can readily explain, if not account for, the manuscripts' striking divergence: as David Mills observes, with two fragmentary exceptions all copies of the cycle postdate the year of its final performance, 1575, rendering the cycle manuscripts more likely a product of the sixteenth century's standardized early-modern English than a literatim transcription of its hypothetical late-medieval exemplar. ${ }^{11}$ In spite of this temporal divergence, there is reason to believe that some traces of the exemplar may still be detectable even in these late copies. As the post-Reformation Late Banns openly admit, those 'grosse wordes you here / which ymport at this day small sense or vnderstandinge' have been 'not altered in many poyntes from the olde fashion' (50-1, 156). ${ }^{12}$ While the swearing off of too much alteration acknowledges that the text has in some points indeed been altered, these lines from the Late Banns also confess an unexpected sense of value attached to preserving the alterity of the cycle's outdated language. Mills finds this attitude unsurprising, given

the pride and affection with which the cycle continued to be regarded in the Chester area, particularly by clerics and devout laymen with scholarly aspirations; the strong antiquarian movement in Chester, which valued the plays as part of the city's history and traditions; and interest in the play text as a book for private reading as well as a piece of practical theatre. ${ }^{13}$

Though spelling would be much more vulnerable than lexis even under such preservationist auspices, if these factors were indeed motivating impulses behind the 'spate of late copying' the Chester cycle enjoyed, we have perhaps greater hope of finding traces of the original late-medieval text with which to draw comparisons to the Pearl manuscript. Taking as our base text Huntington Ms 2, the 'earliest ... most scrupulous and accurate' of the copies, ${ }^{14}$ we begin to notice some curious features relevant to 'Howe', 'Aho.io.o.', and the phonological distinction between /u:/ and /o:/ that these words at first glance appear to indicate. Hankyn's summoning cry at line 45 sounds out three more times in the first half of the play at lines 61, 69, and 161. The last of these is unusual from a southwards-tilted perspective: in multiple manuscripts it is respelled 'Hooe'. Received middle-English phonology would have these two versions of the summoning cry rendered /hu:ə/ and /ho:ə/, <oo> 
customarily representing /o:/ in London's local written dialect. These cannot be the renderings for Huntington ms 2, however, since both words have the same end-rhyme, 'lowe' $(7.46,163)$. That end-rhyme reinforces the homophony of the differently spelled words is significant here since, as McIntosh notes, end-rhymes can be especially valuable in stripping away accumulated layers of copyists' modifications: 'a copyist who does not otherwise adhere to the forms of his exemplar may yet reproduce the spellings of rhyme-forms just as he finds them, so that even a copy at very many removes from the original may nevertheless preserve the authorial rhyme-spellings'. ${ }^{15}$ Further investigation reveals a number of words that freely vary spellings in ways that would usually render differential /u:/ and /o:/ phonemes, eg, <although $>/<$ althoo $>$ $(7.633,620)$ shows the same variation as $\langle$ howe $>/<$ hooe $>$, while 'hold' is spelled four times with $<$ ou $>$, five with $<0\rangle$, at one point appearing differently spelled in successive lines with exactly parallel construction. ${ }^{16}$

McLaughlin argues that this pattern of free variation between /o:/ and /u:/ spellings indicates a phonological characteristic of late-fourteenth-/early-fifteenth-century northwest Midlands dialect, writing that the free alternation of $<\mathrm{ov}$, ou, ow $>$ and $<\mathrm{O}>$ in the Pearl manuscript 'may indicate a lowering of $[\mathrm{u}]$ to $[\mathrm{o}]$ ' such that in many contexts $<\mathrm{O}>$ 'probably represent [s] an unstressed allophone of /uw/'. ${ }^{17}$ Lass also cites the Pearl manuscript as evidence to track the shifting historical relationship between /o:/ and /u:/: as the phonological changes collectively known as the Great Vowel Shift began to gain momentum in the later-fourteenth and fifteenth centuries, he writes, /o:/ appears to raise to /u:/ in the northwest Midlands at the same time that /u:/ begins to round into $/ \mathrm{ou} / .^{18} \mathrm{~A}$ complex picture thus emerges of a linguistic environment where /u:/, /o:/, and /ou/ phonemes shift in and out of allophony over time. This picture certainly does not argue for the phonic equivalence of all possible /u:/ and /o:/ spellings in the Chester Shepherds play; rather it indicates that in Huntington Ms 2, the graphemes $<\mathrm{u}$, ow, ou, oo, o $>$ represented sounds that were phonically close enough to sustain rhyme schemes, could have been grouped together by the ear, and may even have in certain contexts been allophonic in the Cheshire dialect. In this way we can see the play establishing an evolving network of similar verbal sounds perceived as functionally related over the span of the play's performance history.

Examining 'Aho.io.o.' as a verbal, presence-effecting echo rebounding to Hankyn from the margins of the aural field thus opens up important insights into the Chester Shepherds' aural design and the nature of the vocal and relational presence it sustains at the same time that it cues us to the special 
potency of Hankyn's summoning vowel, the 'ow' of 'Howe', and its multiple repetitions, echoes, and reinventions in the Chester Shepherds play's performance. Indeed, counting the Latin echo, Hankyn's summoning vowel sounds eight times over his four-line cry for a companion (7.45-8); review the monologue Hankyn speaks before his cry, and he brims with 'ow', most notably in the end rhymes of the play's second, third, and fourth stanzas. It is as if the pressures of Hankyn's self-imposed solitude build up over the course of his speech, obsessively placing 'ow' in his mouth until it bursts out in a liminal utterance that strikes the horizon of the aural field and transforms it, eradicating the lonely herdsman's seclusion and ratifying his present voice through the introduction of a new persona in relation to whom sonorous presence may arise.

\section{Expanding and Contesting Secular Aurality}

The sonar-like call-and-response of Hankyn's 'howe' is still reverberating when Harvye steps onto the stage: embodying the verbal echo, the newly arrived shepherd re-sounds Hankyn's summoning vowel seven times over his first five lines and completes the rhyme scheme that Hankyn's summons inaugurated:

Yt is no shame for mee to shewe

how I was set for to sowe

with the fether of a crowe

a clowte upon my heele.

Sitt downe.

$(7.49-53)^{19}$

In circulation since the opening words of the play, Hankyn's 'ow' passes on to Harvye. 'Fellowe', Harvye addresses his companion, granting Hankyn the 'fellowshippe' he desired, 'nowe be we well mett ... had wee Tudd heere by us sett' (7.53-5). Now it is Harvye who seems to suffer from want of fellowship and who feels the accompanying urge to cry out 'howe' to an other. He must emit the cry himself, extending Hankyn's echolocation in a chain reaction that insistently calls others into hearing in order to confirm sonorous presence to oneself. Over lines 57-68 Hankyn teaches Harvye how to do just this, how properly to cry out for an other to enter into the dramatic world, and as before, once Harvye emits his version of the cry - 'How, Tudd, Tybbys sonne!' (7.69) — another persona does enter the dramatic world, 
echoing back 'ow' as Harvye did some twenty lines earlier, advancing the chain reaction to its next iteration.

As Harvye's entrance marked a transformation of the aural field from a solitary, anonymous sound space constructed against the public street of Chester to an echoing, dialogic sound space in which mutual presence could arise, Tudd's entrance marks the next phase in the evolution of the play's aurality. Shortly after responding to Harvye's cry — 'Syr in faith nowe I come' (7.70) — Tudd makes a curious request: 'Hankeyn, hold up thy hand and have mee, / that I were on height there by thee' (7.93-4). His words indicate one possible staging particularly coherent with the cycle's later processional format: Tudd asks for help climbing up onto an elevated stage as that of a pageant wagon, 'on height there by thee', suggesting that when he speaks the line he is located in the street among the audience. Where the play-text and Latin stage directions suggest that Harvye's earlier entrance maintains theatrical boundaries intact, Tudd's entrance breaks into dramatic space from the outside, from the previously excluded space of the audience.

In performance, then, Harvye would project his summoning 'how' out into the audience where the actor playing Tudd has been planted. The direction of his cry effectively annexes the audience's full acoustic space to that of the dramatic world; the exclusionary aural field that once ended at the edge of the playing space now spills outside the theatrical boundary, 'straddling' between dramatic and real worlds in exactly the way that Hankyn's speech at the play's opening demurred from doing. The audience in effect becomes the something real 'out there' that Harvye's 'how' rebounds against, the echolocative technique becoming literal when a member of the crowd does in fact answer the call, embody the voice of the echo, and return Harvye's presence-effecting cry. The streets of Chester become continuous with the shepherding fields, and a shared sonorous regime arises through which the diegetic world's native aurality acquires the ability to shape how extradiegetic aural environments and sonorous events make meaning.

Gathered together in community, the three shepherds muster a rustic banquet out of thin air which guild accounts suggest they shared with the audience ${ }^{20}$ in a celebration of newfound 'fellowshippe'. Soon after, Hankyn suggests they call Trowle, their servant and keeper of their flocks, to join their company. This summoning into aurally present fellowship plays out quite differently than earlier iterations of the echolocative chain reaction, however, one indicator among many that Trowle, like the youngest herdsmen in other cycle shepherds' plays, comes endowed with special grace 
and 'moral distinctiveness'. ${ }^{21}$ First, Hankyn sees Trowle before he calls him near: 'Yonder lad that sittes on a lowe / the lowd of this horne shall here' (7.163-4). Before, personae became present within the world through a volley of 'ow'; here, Trowle is present even before Hankyn hails him and can be identified and located in space before the summoning 'hooe' rings out. ${ }^{22}$ Even more unusual, when it comes time for Hankyn to emit the cry, instead of blowing his horn as he said he would, the stage direction indicates that 'Tunc cantabit et dicat Garcius' (7.164 sd). While some critics have taken the direction to indicate that Hankyn is here to play his horn and then Trowle to speak, Rastall has convincingly argued that Trowle is instead here to sing and then go on to begin his speech, ${ }^{23}$ the horn blast not sounding out until line 194 where Trowle first signals his awareness of the shepherds and their summons.

It is as if Trowle is enclosed in an aural bubble, a magic circle that permits him to be visually present to the other three shepherds but divorced from the rules of their aurality. Such an arrangement verges on metatheatre, reproducing the exclusive aural field that Hankyn established at the opening of the play only now with Hankyn, Harvye, and Tudd functioning as the excluded audience and Trowle taking the role of solitary herdsman in the midst of a shepherding world. Indeed, Trowle's first speech strikingly recalls Hankyn's monologue at the play's outset. Like Hankyn, Trowle tends his flocks with great care: where Hankyn reports that 'On wouldes have I walked wylde' (7.1), 'On this wold walke' Trowle and his sheep (7.167); where Hankyn finds 'no fellowshippe ... / save myselfe alone, in good faye' (7.41-2), Trowle asserts there 'are no men here, that noe waye' (7.168). But there are important differences as well. Whereas Hankyn's immediate response to his solitude was to cry into the uncharted space of the 'woulde' in hopes of a reverberant echo, Trowle is content with his circumstances and self-sufficient, his sheep healthy and good company: 'Noe better may bee / of beast that blood and bonne have' (7.171-2). In the world that Trowle inhabits echolocation is useless: 'All is playne, perdee' (7.169), all a terrain stretching flat with no interposing surfaces against which a cry might rebound. Rather than struggle with the forces of nature, Trowle is at peace with the world, not weary nor wandering nor lonesome. No matter who calls out to him, 'ryse I will not but take my rest here' (7.187).

Trowle thus models an alternative manner for inhabiting the sonorous dramatic world, an alternative that contests and extends Hankyn's techniques for inhabiting voice and effecting presence within aurality. The youngest 
shepherd defers the cry for an other characteristic of the senior herdsmen when he opens his mouth to sing; it is the first time we hear song in the play, no small affair in a drama whose climax, aurally speaking, is angelic song. ${ }^{24}$ Notably Hankyn's summoning vowel does not disappear when Trowle ends his song and begins to speak; his first line could contain it in almost every syllable: 'Good lord, looke on mee' (7.165). But this sound is no longer the searching vowel projected out into the world, a voice seeking to confirm its presence to itself by summoning an other into sonorous fellowship. Rather it is a request for grace directed towards God, a distinctly different method for achieving presence through sound. Trowle dismisses Hankyn's earthbound echolocative technique and instead aims his voice upwards, turning his ear heavenward for the echo.

Eventually Hankyn's 'hooe' does penetrate Trowle's aural envelope, inciting a flurry of angry 'ow' in response - 'Thow fowle filth, though thow flytt, I defye thee' (7.197) — and sparking a harsh critique of the trio for their failure to make music, for 'sittinge withowt any songes' (7.205). Importantly this critique does not just land on the shepherds' heads but flows across the theatrical boundary and onto the audience who were earlier aligned in aural community with the herdsmen through the action of Harvye's straddling cry and Tudd's subsequent entrance. Trowle's critique effectively forces the audience to become more keenly aware of their fellowship with the earthy shepherds - they too congregate and watch 'withowt any songes' as the rules of the theatrical game require - and demands that they reflect upon and re-evaluate that fellowship, offering the singing voice and the address to God as a better alternative for effecting presence. Though to launch his critique Trowle must step out of the pleasant and restful pasture, his locus amoenus where he is present before God, this is a fortunate fall since through it a lowly tender of flocks is able to teach multiple audiences that it is the prerogative of divinity alone to call man into presence, to mould the aural field, and to set voice into motion such that God's creation echoes back the divinely summoning cry. ${ }^{25}$

\section{The Sound of Angelic Song}

The most noteworthy inclusion in Ms Harley 2124's Chester Shepherds playscript is a five-lined staff of music notation for the angel's song (fig. 1), the only extant Gloria setting for any of the English mystery cycles. The unique status of this notated Gloria has stimulated significant critical interest in 
and speculation over its performance. Rastall reasons that the notation is an incipit specifying one out of multiple musical settings and proposes that the particular setting it cites was polyphonic, notated in full in an independent document, and composed probably in the mid-sixteenth century by a musician working at Chester. ${ }^{26}$ Investigating the Painters', Glaziers', Embroiderers', and Stationers' Records uncovers intriguing evidence about the vocal forces this song called for, corroborating Rastall's intuition that the cited setting was polyphonic, even if he interprets the documentary evidence differently. The guilds' accounts include regular payments for a quartet of actors listed as 'shepperdes boyes', that is, the four boys who appear near the end of the play to present gifts to the Christ child. Judging by the significant sums they are paid, JoAnna Dutka surmises that these 'shepperdes boyes' were highly trained and expensive choristers from Chester Cathedral. ${ }^{27}$ Such data is puzzling since the four boys' passage is dramatically unimportant, a mere forty-four lines long, and contains no obvious cue for singing. The account books only make sense if we assign the pricey boy singer-actors double duty, not uncommon practice in medieval dramaturgy, ${ }^{28}$ so that they first sing the angel's polyphonic music that they alone had the training to perform and later step on stage to represent the four boys.

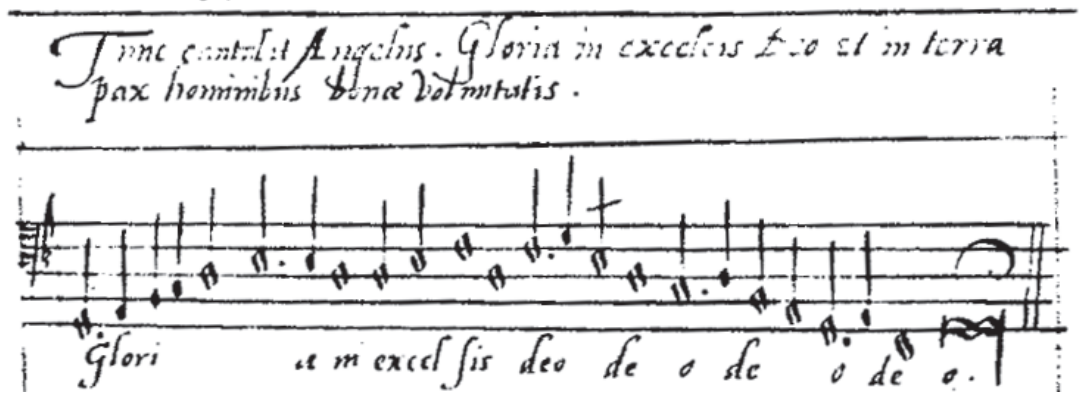

Figure 1. Music notation for the Chester Gloria from BL Ms Harley 2124. Reproduced with permission.

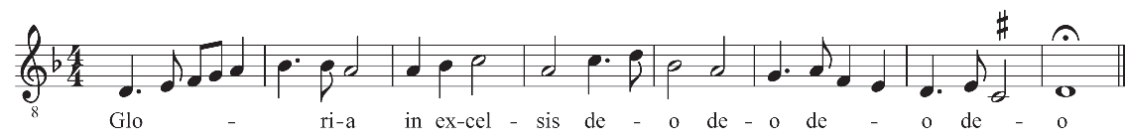

Figure 2. Transcription of the Chester Gloria in modern notation. 
Rastall objects that a multivocal performance of the Gloria conflicts with the play-text, where stage directions and dramatic auditors always refer to the angel with singular verbs or pronouns, but in the course of his objection proposes a solution to this dilemma: it was accepted staging practice to hide singers behind the pageant wagon while a single non-singing actor represented the singing persona on stage. ${ }^{29}$ This possible solution becomes more convincing when we recall that a similar arrangement was already commonplace for liturgical enactments of the nativity story. John Stevens describes the performance of the Ordo Pastorum as part of the divine office during the Christmas season: a single boy 'is positioned up in the roof to the west of the choir "announcing the birth of the Lord in the likeness of an angel" after which 'a number of boys "up in the vaults like angels"' sing the Gloria itself. ${ }^{30}$ Though critics have long discredited the theory of a genetic relationship between liturgical drama and vernacular cycle plays, there is no reason that one dramatic tradition could not borrow from and reinvent the performance effects of the other, that vernacular sacred street theatre could not adapt the liturgical custom of representing the Christmas pageant's angel with a single persona whose voice sounds like a choir of voices.

Indeed, this adaptation may have met practical as much as theatrical needs. For a processional staging, stationing the boy singers in the narrow space behind the tall pageant wagon with the street's architecture rising to their backs and cantilevered in canopies overhead would require the sound of the boys' singing to travel up, out, and around in order to reach the audience's ears. The acoustic consequences would be significant. Their singing would lose some of its focus and its volume could be affected as their sound waves bounced off the acoustically reflective stone-and-plaster architecture and were absorbed into sound-dampening materials like the pageant wagon's backcloth. These performance conditions would have challenged even trained singers and provided all the more reason for four boy singers instead of one or two. The result was a music that sounded as if it emerged from air, not localized in the visible actor's mouth but emitting with otherworldly effect from the space around him.

With all these details in place we arrive at a surprisingly nuanced description for what angel's singing sounded like in late-medieval Chester: like a quartet of trained boys' voices, pure in tone, performing rhythmic melismas, most likely in a polyphonic texture, their sound blended and somewhat diffused, seeming to emerge from the air instead of from the angel's open mouth. The shepherds' commentary on the angel's song — among the longest and 
most valuable examples of aesthetic music criticism penned in the English middle ages - strikingly supports this description. Indicatively a great portion of their observation addresses the location of the angel's voice: its height, 'this mutinge on highe' (7.360); its relation to surrounding architecture, 'that note went over the howse' (7.385); the difficulty of ascertaining its vocal source, 'no man was nere / within our sight' (7.362-3), 'I wyst never whoo' (7.375); and its unlocatability in space, 'I durst not hede wher that yt was' (7.423). They also comment on the high pitch and piercing clarity of angelic timbre, remarking that 'all heaven might not have gone harre, / that note on high when hee up hent' (7.414-5) and compare the angel's voice to bird-song: 'hee so whewted' (7.422) and 'up as a pye hee pyped' (7.417). ${ }^{31}$ Further, they hint at trained boy singers when they acknowledge the superior quality of the angel's voice, 'He had a mych better voice then I have, / as in heaven all other have soe' (7.406-7), and admire the angel's musical decorum, 'on that sadly hee sett him' (7.409), and dynamic control, 'Upon 'hominibus' hee muted' $(7.420){ }^{32}$

More than its acoustic and musical properties, though, it is the verbal content of the angel's song that perplexes and fascinates. In all of the shepherds plays the herdsmen play the angel's alien syllables across their tongues, highlighting their rusticity and in a sense the rusticity of all humanity in comparison with the divine choir. For the Chester shepherds this ludic wordplay grows frenetic around the antiphon's first word: gloria $(7.357 \mathrm{sd})$. Of their seventy-eight lines devoted to the angel's song, fifty dwell on this one word, stretching and wringing and prying it with every variation imaginable: glore, glere, glorye, grorus, glorus, glarus, glorius, glee, glo, glas, glye, glor, glay, gly $(7.361,364,382,384,388,391,392,400)$. Why all the fuss over glo-? The music from Ms Harley 2124 suggests a striking answer: the first, the longest, and the most elaborate melisma of the angel's song occurs on this syllable (see fig. 2), ${ }^{33}$ a melodic texture that would be all the more prominent in a polyphonic setting. The shepherds fix on the most memorable aspect of the musical setting, its opening scalar ascent in a flourish of quick notes. And yet their attraction to glo- is much more than musical appreciation - it is no coincidence that the vowel sound upon which the angel's melisma ascends is $o$, as in 'Aho.io.o.', as in 'howe', at last firmly established in its proper divine context. God sends a cry of joy through his angel, calling the human race to salvation, and humanity echoes back that cry, jubilant, imperfect, unsure of its import. The shepherds suddenly find themselves drawn into presence before God through a dynamic exchange of $(g l) o$ precisely because $(g l) o($ ria $)$ 
means that God has taken on the flesh of corpus Christi and become present in the world which the shepherds inhabit.

\section{The Songfulness of Salvific Aurality}

Song proliferates after the angel's Gloria with six opportunities for musicmaking in the remaining 250 -odd lines. ${ }^{34}$ Three of these stand out for brief comment. In response to Hankyn and Harvye's call to prayerful song (7.442-3), Trowle rouses everyone including the audience to an exuberant outpouring of joy:

Singe we nowe; lett see,

some songe will I assaye.

All men nowe singes after mee,

for musicke of mee learne yee maye.

Famously the song Trowle strikes up is no pious hymn but a popular ditty attested to in all manuscripts but one by its refrain, 'Troly loly loly loo' (7.447 sd). Joseph Ritson considers this refrain to be 'of great antiquity', 35 and it remained popular at least through the reign of Henry VIII from whose court three musical settings survive. Though the attribution is speculative, Dutka identifies Trowle's lyric with one of the settings from Henry VIII's famous songbook:

Trolly lolly loly lo,

Syng troly loly lo!

My love is to the grenewode gone,

Now after wyll I go;

Syng trolly loly lo loly lo!36

Even if we cannot be sure about its accuracy, Dutka's attribution is poignant. The full lyric returns to the problem with which the play began - determining presence in a solitary wilderness - and tackles that problem with the same technique: of the thirty-six vowels in the lyric exactly half are o's. ${ }^{37} \mathrm{We}$ are once more in the earthly, mundane world of the echoing wilderness, one half of a fellowship seeking the absent other who can respond to his vowelladen cry and confirm to him his presence. It is important to remember, though, that it is Trowle who here sings this torrent of o, sings it with his audience instead of compulsively crying it out at his auditors, in the aftermath of a divine flood of $(g l) o$ that inaugurated an entirely new, heaven-sent aurality. 
In Trowle's repeating liquid l's and resonant o's we do not hear a ululating cry into the unknown; rather we hear human admiration and imitation of an angel's melismatic singing, imitations of $(\mathrm{gl}) \mathrm{o}(\mathrm{ria})$, or, better, $(\mathrm{g}) \mathrm{lo}(\mathrm{ria}){ }^{38}$ We do not simply hear a pastoral narrative of lusty adventure in the untamed wood, the unforgiving 'woulde' Hankyn struggles against. Instead we hear an allegory of Christ the good shepherd seeking the soul in the greenwood of the world, the flesh, and the devil. Bridging the theatrical boundary and broadening the aural field of ( $\mathrm{g}$ )lo(ria) to fill the full acoustic space of the Chester play's performance, Trowle replaces the old aurality of shepherdly 'fellowshippe' with a redefined aurality, one that embraces his auditors and invites them through singing into catholic Christian community.

The second songful moment of note comes when the four boys, the cathedral choristers who before gave the angel its polyphonic voice, offer their meagre gifts to the newborn Jesus. The First Boy gives a sturdy bottle missing its stopper, the Second gives his hood, the Fourth his nuthook. The Third Boy's gift, though, is most noteworthy from the perspective of the play's soundedness. He gives 'my pype that soundeth so royallye', a little musical instrument with surprising potency:

Were I in the rocke or in the valey alowe,

I could make this pipe sound, I trowe,

that all the world should ringe

and quaver as yt would fall.

The Third Boy's speech is richly layered after all that has transpired in the play's evolving aural design. His gift of a pipe cites the ox-horn that bore Hankyn's echolocative 'howe' out into the world; his description of the pipe's reverberation 'in the rocke or in the valley' recalls the horn's vocal echoing in the wilderness, 'Aho.io.o.' But this pipe's piping is different. Its sound encompasses all the world; it sets the whole world ringing and trembling, makes the entire earth 'quaver as yt would fall'. This is not the kind of sound emitted by Hankyn's horn, but rather resembles the trumpeting of angels at the end of time - symbolically, the Third Boy who recently sang the angel's part gives the infant Christ, the future judge and king of all mankind, the initializing 'royal' instrument of the last judgment. Thus at an anagogical level the Third Boy's gift of a lowly shepherd's pipe reflects the divine dynamics of $(\mathrm{g}) l o(\mathrm{ria})$ 's aurality, bestowing upon God the prerogative to summon mankind into resurrected presence with the blast of a trumpet at the end of history. 
Finally, as the play comes to an end, Tudd invites the audience to join him and his fellows once more in song, his second-person pronouns straddling the theatrical boundary and again affirming Christian community:

To that blys bringe you

great God, if that thy will bee.

Amen, all singe you;

good men, farewell yee.

The singing of 'Amen' is an appropriate close to the Chester Shepherds play, reiterating its communal Christian aurality, recalling its liturgical counterpart, the Ordo Pastorum, and acknowledging the shepherds' newfound religious vocations, decided upon while they 'singinge walke[d] homwardlye' (7.651-79). This is not the end of the play however. In the mode of a chorus Trowle reappears to conclude the play by stepping to one side of the dramatic world and addressing the crowd directly and self-consciously, mirroring Hankyn's mode of address at the opening of the play. He bids the audience farewell, asks God's blessing for them, declares the play at an end, and bids them farewell one last time: 'Farewell, for wee from you goe nowe' (7.696). He notices a practical reality: the play done, the pageant wagon now needs to be loaded and wheeled to its next station where the players will enact their elaborate drama with its sophisticated and mutable auralities once more.

Cued to the play's aural sophistication, however, we also hear a final salvo in Trowle's closing words. His last line, the last line of the play, concludes with a string of summoning vowels: 'wee from you goe nowe'. Once more the potent sound so fundamentally involved in the play's negotiations of presence, identity, and community irrupts in concentrated form, bridging dramatic and real worlds, Bethlehem and Chester, biblical past and late-medieval present, to take leave of the audience it has sought to draw into the sonorous community of salvation. To be sure, there is no guarantee that every auditor of the play would harmoniously enter into the integrative, ideological forces the play's evolving program of auralities puts into motion — there are ample opportunities for resistant engagement with the play's claims to sonorous meaning, ${ }^{39}$ and there can be little doubt that the play's intricate soundscape shifted and reorganized as it weathered the linguistic, dramaturgical, and censorial vicissitudes of its long and late performance history. Even so, when we choose to amplify the sounded dimension of the Chester Shepherds play as living, breathing performance and attend to its idiomatic, strategic appeals to meaningfulness with keener ears, we discover multiple modes through 
which sound as a sensory phenomenon in its own right bore the force of meaning, and we encounter new ways of understanding the dynamic and sophisticated relationships between late-medieval theatre, its audiences, and their reverberating world.

\section{Notes}

Versions of this article were presented at the 45th International Congress on Medieval Studies in May 2010 and at the 21st International SELIM Conference in September 2009. I am grateful to the participants of both conferences and to the anonymous reviewers at Early Theatre for their instructive feedback. I am also much indebted to Roger Lass for his guidance in matters of late-medieval English phonology.

1 V.A. Kolve glosses Trowle's besting his elder shepherds during the wrestling match as a festive inversion of the master-servant/adult-child hierarchy and thus as a literalization of the Magnificat verse deposuit potentes de sede et exultavit humiles, itself linked to the nativity and to the medieval boy bishop customs of the Advent season. See V.A. Kolve, The Play Called Corpus Christi (Stanford, 1966), 155-8.

2 Bakhtinian analyses of the parodic carnivalesque in the cycle shepherds plays abound, especially for the Towneley Second Shepherds' Play. See Rick Bowers, 'Comedy, Carnival and Grace: The Performance of Mak in the Second Shepherds' Play', English Studies in Canada 28.4 (2002), 583-602; Lee Templeton, 'Cast Them in Canvas: Carnival and the Second Shepherds' Play', Medieval Perspectives 16 (2001), 151-64; and Warren Edminster, 'Foolish Shepherds and Priestly Folly: Festive Influence in Prima Pastorum', Medieval Perspectives 15 (2000), 57-73. Nan Cooke Carpenter, 'Music in the Secunda Pastorum', Speculum 26 (1951), 696-700, DOI: http://dx.doi. org/10.2307/2853061; JoAnna Dutka, Music in the English Mystery Plays (Kalamazoo, 1980), 108-11; and Richard Rastall, Music in Early English Religious Drama, 2 vols (Cambridge, 1996), 1.256-8, 1.344-64, and 2.251-3 all examine the musicological implications of the angel's song and the shepherds' ensuing discussion in these plays.

3 Meg Twycross, 'The Theatricality of Medieval English Plays', Richard Beadle (ed.), The Cambridge Companion to Medieval English Theatre (Cambridge, 1994), 48, 5860. DOI: http://dx.doi.org/10.1017/CCOL9780521864008.003.

4 Hans-Jürgen Diller, 'Theatrical Pragmatics: The Actor-Audience Relationship from the Mystery Cycles to the Early Tudor Comedies', Comparative Drama 23.2 (1989), 158. 
5 Parenthetical citations of play-texts give the sequential pageant number and the quoted line number(s). Citations from the York cycle are taken from Richard Beadle (ed.), The York Plays: A Critical Edition of the York Corpus Christi Play as Recorded in British Library Additional ms 35290, Early English Text Society Supplementary Series 23 (Oxford, 2009).

6 All citations of the Chester Shepherds play are taken from R.M. Lumiansky and David Mills (eds), The Chester Mystery Cycle, Early English Text Society Supplementary Series 3 (London, 1974).

7 Rastall, Music in Early English Religious Drama, 1.349.

8 Angus McIntosh, A Linguistic Atlas of Late Medieval English, 4 vols (Aberdeen, 1986), 1.5.

9 Roger Lass, 'Phonology and Morphology', Norman Blake (ed.), 1066-1476, The Cambridge History of the English Language, 6 vols (Cambridge, 1992-2001), 2.32. DOI: http://dx.doi.org/10.1017/CHOL9780521264754.003.

10 John C. McLaughlin, A Graphemic-Phonemic Study of a Middle English Manuscript (The Hague, 1963), 12-16; Lawrence M. Clopper (ed), REED: Chester (Toronto, 1979), 13-15.

11 David Mills, 'The Chester Cycle', Richard Beadle (ed.), The Cambridge Companion to Medieval English Theatre (Cambridge, 1994), 109-10. DOI: http://dx.doi .org/10.1017/CCOL9780521864008.006.

12 F.M. Salter, 'The Banns of the Chester Plays', The Review of English Studies 16.62 (1940), 143, 147, DOI: http://dx.doi.org/10.1093/res/os-XVI.62.137. Notably, one of the 'grosse wordes' that the Late Banns singles out for its archaism, 'in feare', features prominently in the Chester Shepherds play $(7.131,208,358)$, in large thanks to the play's exploration of the notion of 'fellowshippe'.

13 Mills, 'The Chester Cycle', 111.

14 Ibid.

15 McIntosh, Linguistic Atlas, 1.17.

16 The <ou> spellings appear on lines 252, 271, 272, 291; <0> spellings appear on lines 93, 206, 233, 292, 615. Lines 291-2 are especially striking in this regard: 'but I must needes hould the harmes that I have. / 2 PAsTOR That I have needes must I hold ...'

17 McLaughlin, A Graphemic-Phonemic Study, 91. McLaughlin's notation /uw/ is unusual. Appended to other vowels, /w/ indicates dipthongization in McLaughlin's text, so in combination with /u/, I have taken it to indicate the allophonic equivalent of /uu/, which is to say, /u:/.

18 Roger Lass, 'Phonology and Morphology', Roger Lass (ed.), 1476-1776, The Cambridge History of the English Language, 3.78-80. DOI: http://dx.doi.org/10.1017 /CHOL9780521264761.004. Lass argues that /u:/ > /ou/ dipthongization is rarely 
reflected in middle English texts because <ou, ow>, the normal spelling for /u:/, was also already a satisfactory digraph for /ou/. His graph on 78 illustrates the shifting relationship between /o:/ and /u:/ nicely: two s-curves representing pre-GVS [o:] and post-GVS [u:] intersect at a 'notional midpoint' where the two pronunciations exist in roughly equal distribution. It is important to remember that this midpoint does not indicate the neutralization of phonological difference between /o:/ and /u:/, merely that speakers would have encountered both forms with equal frequency, demanding a consequent degree of aural fluency for both forms. To address the possible allophony of these phonemes in the late medieval northwest Midlands, one might look to McLaughlin's graphonemic system for the Pearl manuscript (McLaughlin, A Graphemic-Phonemic Study, 134-40) to argue that the resultant phoneme may have sounded closer to /u:/, given its striking number of allographemic options as both short and long vowel, <v, v-e, vv, v3 o, o-e, oo, ow, ov, o3, oe>, in comparison to those similarly available for /o:/, <o, o-e $>$. McIntosh's cautions against the hazards of phonological conjecture based on documentary evidence alone are here well taken, of course.

19 If we include short vowels in the network of sounds related to Hankyn's summoning vowel, the number of opportunities for its re-sounding in Harvye's opening speech jumps dramatically: fifteen possibilities over five lines, with four possibilities each in the first two.

20 R.M. Lumiansky and David Mills (eds), The Chester Mystery Cycle: Commentary, Early English Text Society Supplementary Series 9 (London, 1974), 108.

21 Rosemary Woolf, The English Mystery Plays (London, 1972), 187. Woolf observes that in the Chester Shepherds play 'each step forward in religious understanding is taken first by the boy'.

22 There is still a strong suggestion, however, that knowledge of who and where Trowle is still sonorous in nature, the wordplay of lines 163-4 linking 'lowe', 'lowd', and 'Trowle' — place, sound, and identity — to the 'Hooe' that powers Hankyn's presence-effecting technique.

23 Richard Rastall, 'Music in the Cycle', The Chester Mystery Cycle: Essays and Documents (Chapel Hill, 1983), 127.

24 The Painters', Glaziers', Embroiderers', and Stationers' Charter (мs Harley 2054) suggests that the play's shepherds were not the only ones to recognize the angel's song as the play's key dramatic event. In order to justify the four guilds' joint production of the Shepherds play, the Charter states that 'pe haue bine tyme out of minde one Brotherhood for the costs \& Expences of pe plae of pe shepperdes wach with pe Angells hyme', their description of the play singling out the angel's song as 
its most noteworthy (and perhaps most expensive) element. Clopper, REED: Chester, 30 .

25 Trowle's typological alignment with Adam is supported by Lumiansky and Mills who observe that Trowle's Christian name, otherwise undocumented in late-medieval England, is actually the name of a farming implement, a trowel or shovel. His name might thus be glossed as a reference to Adam's post-lapsarian sentence to work the land and labor for the food he had in effortless abundance in the Garden (Gen. 3:16-7). See Lumianski and Mills, The Chester Mystery Cycle: Commentary, 109.

26 Rastall, Music in Early English Religious Drama, 1.86-7 and 1.152-4. We have no musical information about the Angel's Gloria prior to this date, though it is not inconceivable that the music we do have from Ms Harley 2124 would share stylistic features with earlier versions of the song which were periodically reworked and recomposed.

27 Dutka, Music in the English Mystery Plays, 79. Account Book I from the Painters', Glaziers', Embroiderers', and Stationers' Records indicates handsome wages paid to 'iiij shepperdes boyes', $2 \mathrm{~s} 8 \mathrm{~d}$ in 1568 , $4 \mathrm{~s}$ in 1572 , 3s in 1575 . Compared to the principal actors' wages - between $2 \mathrm{~s}$ and $2 \mathrm{~s} 2 \mathrm{~d}$ for Trowle, $2 \mathrm{~s}$ for Hankyn, 20d each for Harvye and Tudd, and a scant $6 \mathrm{~d}$ for the angel — this is an unusually large sum for the boys' brief speaking role on stage. Further confirming their identity, the accounts for 1568 also record a visit 'to speke with mr Chaunter for shepertes boyes'; following Dutka, Rastall identifies 'mr Chaunter' as Sir John Genson, precentor of Chester Cathedral. Clopper, REED: Chester, 81-4, 93, 107; Rastall, Music in Early English Religious Drama, 2.292.

28 Richard Rastall, 'Music in the Cycle Plays', Marianne G. Briscoe and John C. Coldewey (eds), Contexts for Early English Drama (Bloomington, 1989), 204.

29 Rastall, Music in Early English Religious Drama, 2.293.

30 John Stevens, Words and Music in the Middle Ages: Song, Narrative, Dance and Drama, 1050-1350 (Cambridge, 1986), 339-40.

31 The comparison to the pye's song is probably tongue-in-cheek, considering the magpie's notoriously unmelodious voice.

32 This last comment could equally refer to the acoustic environment's unpredictable effect on the boys' sound.

33 Rastall's remarks on music notation in the York cycle help clarify the discrepancy in text underlay between figures 1 and 2: 'In most cases the text was copied before the music, as was usual ... while there are no signs that the scribe encountered spacing problems in copying the words, there are inconsistencies in the spacing of the music that obviously derive from the constraints of a previously-copied text'. Rastall, Music in Early English Religious Drama, 1.123-4. 
34 These opportunities occur at 7.447 sd ('troly, loly, loly, loo'), 7.476 ('singe we all, I read, / some myrth to his majestee'), $7.597 \mathrm{ff}$ (the entrance of the four boys, played by boy choristers), $7.625 \mathrm{ff}$ (the presentation of a musical pipe to the infant Jesus), 7.651ff ('Brethren lett us all three / singinge walke homwardlye'), 7.691 ('Amen, all singe you'). Rastall, Music in Early English Religious Drama, 2.253-6 examines these potential musical cues more fully.

35 Qtd from Dutka, Music in the English Mystery Plays, 79.

36 Ibid, 63. The lyric's text is taken from John Stevens, Music and Poetry in the Early Tudor Court (Cambridge, 1961), 401.

37 Phonologically we might expect the <o>'s of 'Trolly lolly loly lo' to be more open (/o:/) than the kind of vowel associated with Hankyn's 'Howe'. If true, such a difference could function in more than one way: it might extend the range of vowels that function as summoning vowels even further, or alternatively it might point up a difference between affirming Christian community among mortal men and receiving divine grace through the audition of angelic $(g l) o($ ria) .

38 The link between gloria and loly can be linguistically furthered. The i vowel of gloria is the same as the y vowel in loly, and rhotacistic shift from intervocalic $r$ to $l$ is a well-known phonological phenomenon. Thus loly can be styled a version of gloria stripped of its first and last letters.

39 For example, in describing the angel's Gloria, Hankyn recounts that 'When hee sange I might not be sorye; / through my brest-bonne bletinge hee bored' (7.402-3). On the one hand, his description could be taken to indicate the qualities of the boy choristers' vocal sound, the corporeal nature of audition, and even the heart-felt emotional appeal of angelic song. On the other hand, it is difficult to ignore the implied violence of the angel's sternum-piercing 'bletinge'; the 'sorye' that Hankyn denies feeling takes on a decidedly more physical dimension, its invocation of the wounded body problematizing the socially integrative, salvific environment that angelic sonority and the aurality arising therefrom strive to foster. 
